DOI: $10.21802 /$ artm.2019.2.10.144.

УДК 612.06:57.034

\title{
ЗНАЧЕННЯ ХРОНОРИТМІВ У РЕГУЛЯЩЇ ФІЗІОЛОГІЧНИХ ФУНКЦІЙ ОРГАНІЗМУ ЛЮДИНИ: ОГЛЯД ЛІТЕРАТУРИ
}

\author{
С.Б. Семененко ${ }^{1}$, І.Р. Тимофійчук ${ }^{2}$, Л.Д. Борейко ${ }^{3}$, О.І. Юрків ${ }^{4}$, К.В.Слободян ${ }^{5}$
}

Вищий державний навчальний заклад Украйни „Буковинський державний медичний університет”, кафедра фізіології ім. Я.Д. Кірменблата, Чернівиі Украӥна,

${ }^{1}$ Researcher ID 1-1015-2016, ORCID ID: 0000-0002-6124-1938,

${ }^{2}$ Researcher ID 1-1185-2016, ORCID ID: 0000-0003-2617-9697,

e-mail: semenenko.svitlana@bsmu.edu.ua

Резюме. Згідно з даними літературних джерел, біологічні ритми людини - це певні частоти, від швидкості і сповільнення яких залежить функціонування органів і систем організму людини, iї психологічний стан. У здорових людей ритми фізіологічних процесів синхронізовані як між собою, так і з ритмами навколишнього середовища, а синхронізація біоритмів, збереження іх фазових співвідношень забезпечують оптимальні умови функціонування організму і $є$ ознакою здоров'я.

Роль епіфізу і епіфізарного гормону мелатоніну в добовій і сезонній ритміці, режимі сну-активності на сьогоднішній день $\epsilon$ беззаперечною. У тварин і людини секреція мелатоніну епіфізом співпадає зі звичайними годинами сну. Існує гіпотеза, що мелатонін відіграє важливу роль у відкритті так званих воріт сну та в гальмуванні режимів активності. Секреція мелатоніну підпорядкована циркадіанному ритму. Концентрація гормону в крові максимальна в темний час доби, мінімальна - у світлий. Синтез і активність гормону збільшується після заходу сонця, а пік концентрації відзначається близько 3-ї години ночі.

Мета цього дослідження полягає у вивченні хроноритмів регуляції фізіологічних функцій організму людини та аналізі впливу десинхронозу.

Матеріали і методи. Аналіз вітчизняної та зарубіжної літератури, де висвітлюються фізіологічне значення хроноритмів та проблеми десинхронозу.

Обговорення результатів. Аналіз змін хроноритмів та їх неузгодженість допомагає визначати нові підходи для діагностики, профілактики та вдосконалення часових схем терапевтичних заходів при захворюваннях різних форм перебігу.

Висновки. Отримані дані вказують на вплив процесів десинхронозу на органи і системи організму та пояснюють роль механізмів адаптації організму до навколишнього середовища.

Ключові слова: хронобіоритми, мелатонін, шишкоподібна залоза, супрахіазмальні ядра гіпоталамуса, десинхроноз.

Вступ. Згідно з даними літературних джерел, біологічні ритми людини - це певні частоти, від швидкості і сповільнення яких залежить функціонування органів і систем організму людини, іiі психологічний стан. За час існування життя на Землі сформувались певні цикли, які точно і періодично повторюються в часі і просторі. Відповідно до них відбуваються багато процесів в людському організмі. Якщо людина живе не у відповідності з цими процесами, настає десинхроноз - порушення роботи хронобіоритмів [1].

Обгрунтування дослідження. Про ритмічну організацію окремих функцій організму лікарям відомо давно [1]. У тібетській медицині поняття біоритмів стало базовим в уявленні про функціонування організму, а їх вивчення сформувалось у XX сторіччі як напрям медико-біологічних досліджень [2]. Встановлено існування множини періодичних процесів, різнобічність їх зв'язків у біологічних системах [3]. Це сприяло визнанню принципу ритмічності як універсальної форми організації живої природи. У здорових людей ритми фізіологічних процесів синхронізовані як між собою, так і з ритмами навколишнього середовища [4], а синхронізація біоритмів, збережен- ня їх фазових співвідношень забезпечують оптимальні умови функціонування організму і $є$ ознакою здоров'я [5].

Мета цього дослідження полягає у вивченні хроноритмів регуляції фізіологічних функцій організму людини та аналізі впливу десинхронозу.

Матеріали і методи. Аналіз вітчизняної та зарубіжної літератури, де висвітлюється фізіологічне значення хроноритмів та проблеми десинхронозу.

Обговорення результатів. Адаптація організмів у процесі еволюції відбувалася в напрямку розвитку їх структурної організації і узгодженості у часі та просторі діяльності різних функціональних систем [6]. Над проблемою сприйняття часу тваринами і людиною працювали І.П. Павлов, В.М. Бехтерєв, С.С. Корсаков. Екологічні і фізіологічні аспекти ритмічних процесів вивчав В.В. Слонім. Роль біоритмів у регуляції функцій організму, їх зміни в умовах космічного польоту - В.В. Парін.

Стабільність періодичності зміни освітленості, температури, вологості, геомагнітного поля й інших параметрів довкілля, зумовлених рухом Землі і Місяця навколо Сонця, дозволила живим системам у 
процесі еволюції виробити стабільні і стійкі до зовнішньої дії часові програми, проявом яких є біоритми [7].

Л.О. Бондаренко вважає, що всі фізіологічні процеси мають ритмічний характер і проходять із визначеною періодичністю на різних рівнях організації - від молекулярного до організмового і популяційного, тому ритми окремих показників і функцій у нормі синхронізовані між собою, що забезпечує високу надійність функціонування організму, а також завдяки ритмічним змінам стає можливим існування живих організмів в складному та динамічному середовищі. Фотоперіод відіграє значну роль у синхронізації циркадіанних ритмів функціонування живих істот, забезпечуючи всім органам і системам умови для виявлення максимальної активності вдень і відпочинку вночі [6].

Ритмічність розглядається як обов'язкова властивість живої матерії на всіх рівнях організації, а вивчення ритмів функціонування різних систем організму, чинників, що впливають на їх формування, представляє безпосередній інтерес для сучасної біології і медицини [8].

3'ясуванням організації біологічних систем, ролі чинника часу у здійсненні біологічних явищ $\mathrm{i}$ поведінці живих систем, природи, умовами виникнення і значення біоритмів для організмів займається біоритмологія. Один із напрямів біології - хронобіологія - вивчає біоритми та механізми, що лежать в їх основі [9].

Н.А. Агаджанян встановив, що на межі біоритмології і клінічної медицини знаходиться хрономедицина, яка вивчає біоритми у процесі перебігу різних захворювань, розробляє раціональні схеми лікування і профілактики, з урахуванням біоритмів і їх порушень [10].

Біоритми - результат природнього добору. У боротьбі за існування виживали тільки ті організми, які могли сприймати час і реагувати на нього. Відомо близько 900 функцій, які мають добову періодичність. Різні функції організму мають неоднаковий ритм інтенсивності [11].

Характер змін добового ритму функцій визначається дією етіологічного чинника та відображає специфіку патологічних процесів, які викликали таку перебудову, тобто носить діагностичну інформацію. Дослідження хронобіологічних закономірностей створює теоретичну базу для розробки методів виділення факторів ризику розвитку, ранньої діагностики, прогнозу патології. Досвід інших країн може бути використаний лише частково, оскільки на хронобіоритми впливають спосіб життя, інтенсивність фізичного навантаження упродовж доби, співвідношення тривалості періодів сну і активності, пора року. Від корекції хронобіологічних порушень залежить злагодженість функціонування структур організму, отже, повноцінне відновлення [8].

Упродовж доби змінюється інтенсивність мітотичного поділу: найвища швидкість поділу клітин у ранкові години, вночі вона знижується. Активність у ниркових клубочках найвища між 3 год ночі і 6 год ранку [9]. У більшості людей найвища біоелектрична активність мозку спостерігається ранком (з 8 год до 12 год), ввечері (між 17 год і 19 год). Проте є індивідууми, в яких висока працездатність припадає на нічні години (особливо при розумовій праці) [10].

Кількість кров'яних пластинок у периферичній крові людини зменшується вночі і збільшується в ранкові і денні години. Вміст ангіотензину найвищий ранком і знижується до мінімуму о 18 год, тому дані добової активності різних систем людини необхідно враховувати у клініці [11]. Для визначення ритмів, які синхронні з ритмами середовища, вживають терміни циркадіанний (навколодобовий), циркатідальний (навколоприливний), циркалунарний (навколомісячний), циркануальний (навколорічний) [7].

Для опису ритму використовують наступні параметри: період або частоту, амплітуду - максимальне відхилення від середньої, фазу - позитивну або негативну, акрофазу - час максимального відхилення [8]. При аналізі багатьох фізіологічних параметрів можна виявити денні відтворювані типи піку величини цього параметру і його найнижче значення [10].

Виділяють ритми високої, середньої і низької частоти. Високочастотні ритми включають біоритми 3 періодом від долі секунди до 30 хв. До них відносять ритми електричної активності головного мозку, м'язів серця, ритм дихальних рухів [2]. Реєстрація високочастотних ритмів органів і тканин широко використовується для діагностики різних захворювань і оцінки функціонального стану відповідних органів і систем [10].

Згідно 3 класифікацією Халберга біоритми поділяють на групи залежно від їх частоти:

1. високочастотні (менше 0,5 год).

2. Середньої частоти: ультрадіанні (від 0,5 год до 20 год), білядобові, інфрадіанні (від 28 год до 6 діб).

3. Низької частоти: білянедільні, навколомісячні, білярічні.

Залежно від біологічної ролі, ритми розглядають як адаптивні, так і фукціональні [11].

Прийнято концепцію про циркадіанну систему організму, функціональними ланками якої є супрахіазмальні ядра гіпоталамуса (СХЯ), шишкоподібна залоза (ШЗ), сітківка і нервові шляхи, що їх сполучають [6]. СХЯ розглядаються як основний генератор біоритмів більшості функцій організму, що надзвичайно чутливий до впливу різних чинників довкілля [7].

Дослідженнями Е.Б. Арушаняна встановлено, що найважливішим регулятором активності СХЯ $є$ нейрогормон мелатонін, що синтезується здебільшого в епіфізі мозку у темновий проміжок доби і виконує роль основного сигналу, який узгоджує ритми функцій імунної та ендокринної систем із коливаннями освітлення і температурою навколишнього середовища [11].

Ендогенна регуляція продукції мелатоніну здійснюється СХЯ, а зовнішня корекція - фотоперіодом [11].

Виділяють два види десинхронозу - внутрішній (неузгодженість біологічних ритмів організму) i зовнішній (порушення синхронізації власних біоритмів організму з ритмами навколишнього середови- 
ща). Десинхронози можуть бути як причиною патологічних станів, так і супроводжувати їх [10].

Прояви десинхронозу відмічені при багатьох захворюваннях серцево-судинної, дихальної, ендокринної, травної, сечовивідної та інших систем. Це проявляється порушенням сну і настрою, часу рефлексу, екскреторної функції нирок, сезонною депресією, артеріальною гіпо- та гіпертензією 3 нічним підвищенням кров'яного тиску, сезонним загостренням виразкової хвороби, бронхіальною астмою, пітливістю долонь, колагенозами та іншими хронічними захворюваннями. Особливо помітні зміни температури тіла. Вночі вона приблизно на $1^{\circ} \mathrm{C}$ нижча, ніж вдень [5].

Обговорення результатів. На сьогодні біоритмічні підходи в Україні розвиваються практично у всіх галузях медицини, так як прогнозовані циркадіанні коливання можуть допомогти в діагностиці певних захворювань, а метою хронотерапії $\epsilon$ синхронізація лікування з внутрішніми коливаннями інтенсивності патологічних процесів.

Висновки. Аналіз змін хроноритмів та їх неузгодженість допомагає визначати:

1. Нові підходи для діагностики, профілактики та вдосконалення часових схем терапевтичних заходів при захворюваннях різних форм перебігу.

2. Вплив процесів десинхронозу на органи i системи організму.

3. Роль механізмів адаптації організму до навколишнього середовища.

\section{References:}

1. Bedont JL, Newman EA, Blackshaw S. Pattering, specification, and differentiation in the developing hypothalamus. Wiley Interdiscip Rev Dev Biol. 2015; 4 (5):445-68.

2. Semenenko SB, Karatieieva SU, Slobodian KV, Bacun $\mathrm{OV}$, Yurkiv OI. Peculiairities of the influence nitrogen monoxides synthesis blockade on circadian organization of kidney acid-regulating function under conditions of pineal gland hyperfunction. Wiadomosci Lekarskie. 2018; LXXI (9):1681-1684.

3. Manchester LC, Coto-Montes A, Boga JA, Andersen LP, Zhou Z, Galano A, et al. Melatonin: an ancient molecule that makes oxygen metabolically tolerable. J. Pineal Res. 2015; 59(4):403-19.

4. Vinod C, Jagota A. Melatonin reduces traumatic brain injury-induced oxidative stress in the cerebral cortex and blood of rats. Neural Regen. Res. 2016; 9(11):1112-1116. 5. Bondarenko OV. Melatonyn $\mathrm{v}$ zhyzny cheloveka. Karachentsev YuY, redaktor 100 yzbrannыkh lektsyi po эndokrynolohyy. Vыр. 2. Kharkov: SAM.; 2015, P.761776.

6. Labunets IF. Rol epifiza v rehuliatsii biorytmiv funktsii imunnoi systemy pry starinni [dysertatsiia]. Kyiv; 2012. P.320.

7. Rappoport SY, redaktor. Melatonyn: perspektyvы prymenenyia v klynyke. Moskva: YMA-PRESS; 2012. P.172.

8. Venegas C, Garcia JA, Esgames G, Ortiz F, Lopez A, Doerrier C, et al. Extrapineal melatonin: analysis of its subcellular distribution and daily fluctuations. J. Pineal res. 2012; 52(2):217-27.
9. Pekny M, Wilhelmsson U, Pekna M. Melatonin antioxidative defense: Therapeutical implications for aging and neurodegenerative processes. Neurotox. Res. 2014; 23(3):267-300.

10. Agadzhanyan NA, Brunin DV, Radysh IV. Chronophysiological features of Central hemodynamic in women of reproductive age. Technol Liv Sys. 2014; 11(1):3-4.

11. Arushanian ЭВ. Hormon mozghovoi zhelezы эруfyza: melatonyn Unyversalnыi estestvennыi adaptohen .Uspekhy fyzyol. nauk. 2012; 43 (2):82-100.

\section{УДК 612.06:57.034 \\ ЗНАЧЕНИЕ ХРОНОРИТМОВ В РЕГУЛЯЩИИ ФИЗИОЛОГИЧЕСКИХ ФУНКЦИЙ ОРГАНИЗ- МА ЧЕЛОВЕКА: ЛИТЕРАТУРНОЕ ОБОЗРЕНИЕ}

С.Б. Семененко ${ }^{1}$, И.Р. Тимофийчук ${ }^{2}$, Л.Д. Борейко ${ }^{3}$, О.И. Юркив ${ }^{4}$, К.В. Слободян ${ }^{5}$

Высшее государственное учебное заведение Украинь „,Буковинский государственный медицинский университет”, кафедра физиологии им. Я.Д. Киршенблата, Черновиьь, Украина,

${ }^{I}$ Researcher ID 1-1015-2016,

ORCID ID: 0000-0002-6124-1938,

${ }^{2}$ Researcher ID 1-1185-2016,

ORCID ID: 0000-0003-2617-9697,

e-mail: semenenko.svitlana@bsmu.edu.ua

Резюме. Согласно данным литературы, биологические ритмы человека - это определенные частоты, от скорости и замедления которых зависит функционирование органов и систем организма человека, его психологическое состояние. В здоровых людей ритмы физиологических процессов синхронизированы как между собой, так и с ритмами внешней среды, а синхронизация биоритмов, сохранение их фазовых соотношений обеспечивают оптимальные условия функционирования организма и являются признаком здоровья.

Роль эпифиза и эпифизарного гормона мелатонина в суточной и сезонной ритмике, режиме снабодрствования на сегодняшний день есть бесспорной. Существует гипотеза, что мелатонин играет важную роль в торможении режимов активности, а не в прямом действии на сомногенные структуры головного мозга. Секреция мелатонина подчинена циркадианному ритму. Концентрация гормона в крови максимальная в темное время суток, минимальная - в светлое. Синтез и активность гормона увеличивается после заката солнца, а пик концентрации отмечается приблизительно в 3 часа ночи.

Целью нашего исследования есть изучение хроноритмов в регуляции физиологических функций организма человека и анализ влияния десинхроноза.

Материалы и методы. Анализ отечественной и зарубежной литературы, где освещается физиологическое значение хроноритмов и проблемы десинхроноза.

Результаты. Анализ изменений хроноритмов и их несогласованность помогает определять новые подходы для диагностики, профилактики и усовер- 
шенствования часовых схем терапевтических мероприятий при заболеваниях разных форм течения.

Выводы. Полученные результаты указывают на влияние процессов десинхроноза на органы и системы организма и объясняют роль механизмов адаптации организма к внешней среде.

Ключевые слова: хронобиоритмы, мелатонин, шишковидная железа, супрахиазмальные ядра гиппоталамуса, десинхроноз.

\section{UDC 612.06:57.034}

CHRONORHYTHMS SIGNIFICANCE IN REGULATION OF PHYSIOLOGICAL FUNCTIONS OF HUMAN ORGANISM: LITERATURE REVIEW

\author{
S.B. Semenenko ${ }^{1}$, I.R. Timofiychuk ${ }^{2}$, L.D. Borejko ${ }^{3}$, \\ O.I. Yurkiv ${ }^{4}$, K.V. Slobodian ${ }^{5}$
}

Higher State Educational Establishment of Ukraine «Bukovyna State Medical University», department of Physiology named after Ya.D. Kirshenblat, Chernivtsi, Ukraine, ${ }^{1}$ Researcher ID 1-1015-2016,

ORCID ID: 0000-0002-6124-1938,

${ }^{2}$ Researcher ID 1-1501-2016,

ORCID ID: 0000-0001-5601-2244,

e-mail: semenenko.svitlana@bsmu.edu.ua

Abstract. According to literary sources, biological rhythms of humans are certain frequencies, the speed and slowing down of which depends on the functioning of organs and systems of the human body, its psychological state.

About the rhythmic organization of individual functions of the body, doctors know for a long time. In healthy people, the rhythms of physiological processes are synchronized both with each other, and with the rhythms of the environment, while the synchronization of biorhythms, the preservation of their phase relations provide optimal conditions for the functioning of the organism and is a sign of health.

Although the modern man has created an artificial temperature environment around him, but the temperature of his body varies over the course of the day, as many years ago, is that body temperature depends on the velocity of biochemical reactions.

By studying the organization of biological systems, the role of the factor of time in the implementation of biological phenomena and the behavior of living systems, nature, conditions of origin and importance of biorhythms for organisms is engaged in biorhythmology. One of the areas of biology chronobiology - studies biorhythms and mechanisms underlying them. The role of epiphysis and epiphyseal hormone melatonin in daily and seasonal rhythm, the sleep-activity mode is today uncontroversial. There is a hypothesis that melatonin plays a role in the discovery of so-called sleep gates, inhibition of activity regimes, and not in direct action on the somnogenic structures of the brain. With age, the activity of the epiphysis decreases, so the amount of melatonin decreases, the sleep becomes superficial and restless. Insomnia and sleep deprivation disappear, there comes a healthy, strong sleep that relieves fatigue and nervousness. During a calm, strong sleep in the body normalizes the work of all internal organs and systems, there is a relaxation of the muscles, resting the nervous system, the brain has time to process the information accumulated during the day, because of which the person feels active and healthy.

Secretion of the melatonin is subjected to circadian rhythm. The concentration of the hormone in the blood is maximum in the dark, minimum - in the light. At night, its concentration is 5-10 times higher than in the afternoon. Synthesis and activity of the hormone gradually increases after sunset, and the peak concentration is observed at around $3 \mathrm{am}$ at night. The maximum amount of melatonin is synthesized in young people, with age the synthesis gradually decreases until the end of age. Seasonal fluctuations in hormone levels in human blood are also observed.

The purpose of our work is to study the chronorhythms in the regulation of physiological functions of the human body and to analyze the influence of desynchronosis.

Materials and methods. Analysis of Ukrainian and foreign literature, which highlights the physiological significance of chronorhythms and problems of desynchronized ones.

Results of the research and their discussion. Analysis of changes in chronorhythms and their inconsistency helps to identify new approaches for diagnosis, prevention and improvement of timelines of therapeutic measures in diseases of various forms of course.

Conclusions. The obtained data indicate the influence of the processes of desynchronosis on organs and systems of the organism and explain the role of mechanisms of adaptation of the organism to the environment.

Keywords: chronorhythm, melatonin, pineal gland, suprachiasmatic nuclei of the hypothalamus, desynchronosis. 